\title{
CLOSED TERRITORIAL DISTRIBUTION: AN OPENING QUESTION IN THE SHERMAN ACT*
}

\author{
Christopher D. STONe†
}

I.

\begin{abstract}
$\lambda^{\mathrm{M}}$ MANUFACTURER who does not own distribution facilities reaching out as far as the consuming public must negotiate his product's way to the market through a maze of distributing middlemen. From time to time, in the give and take of manufacturer-distributor bargaining, there evolve patterns of distribution in which the manufacturer retains enough control over the product, even after he has "sold" it, to limit his distributors from competing with one another in their resale efforts. These curtailments on intrabrand competition fall into two general categories: limitations on dealer price, through resale price maintenance, and limitations on dealer territory, through exclusive territorial distribution and closed territorial distribution. 1

In exclusive territorial distribution, the manufacturer divides his marketing area into districts, covenanting with one distributor in each district not to permit his product to be distributed by anyone else having a place of business located within the specified territory. Closed territorial distribution goes a step further in that the distributor selected from each territory is, in terms, forbidden even to send salesmen or detail men into the territory of the neighboring distributors, much less to establish a place of business there. Under some such arrangements, if a customer who has a residence or place of business in one territory goes to buy in an adjacent territory, the seller may have to pay over some part of the sales price to the distributor who has been "infringed upon."2

Under either type of territorial security, not only is a franchised distributor

\footnotetext{
* The author is indebted to Dean Eugene V. Rostow and Ward S. Bowman, Jr., Professor of Law and Economics, Yale Law School, who, true to the Socratic tradition, posed only questions, and are innocent of the author's answers; and to Joel J. Finer and Alan R. Novak for the fruits of comradely and patient debate.
}

† Fellow in Law and Economics, University of Chicago Law School.

${ }^{1}$ A third curtailment of this nature could arise where a single product has two distinguishable end uses, the manufacturer and distributors agreeing that distributor $A$ will distribute only for end use $x$, distributor $B$ for end use $y$. $C f$. Champion Spark Plug Co., 50 F.T.C. 30 (1953).

2 Such was the nature of the restriction in the case of United States v. White Motor Co., 194 F. Supp. 562 (N.D. Ohio 1961), discussed infra at p. 308. A White distributor has informed the author that the penalty runs to about $\$ 100$ out of an average $\$ 900-\$ 1,000$ gross profit on a sale. 
secured against the entry of potential rivals handling the same wares, but even as between existing franchisees competition is curtailed in all dimensions of buyer values-terms of purchase, delivery, warranty, installation and maintenance-as well as in price. The degree of curtailment will vary according to the size of the territory assigned, the ratio of transportation costs to value, and whether the franchise is exclusive or closed. The distinction between closed and exclusive territories becomes important when market conditions in one area enable its distributor to advance his "price"' 3 above that which the neighboring area's distributor is able to demand in his own vicinity. At a certain point, disparity in price levels will attract the distributor in the less favorable market to undertake the cost of invading the other territory. 4 In such circumstances, under exclusive territorial distribution, cross-territorial selling would arise to place a ceiling on the price that can be charged by each of the product's distributors. Closed territorial distribution, however, will block competition between the distributors of a product no matter how great the disparity among the prices they are able to demand in their own areas.5

At this stage of the Sherman Act's ${ }^{6}$ development, it may fairly be said that any scheme effective in achieving the first of these methods of preventing intrabrand competition, resale price maintenance, would be found unlawful per se.7 With respect to exclusive territorial distribution, several federal appellate decisions indicate that such a distribution pattern would not be unlawful per se, but, rather, would be subject to the rule of reason: If the exclusive distributorship did not appear "part and parcel of a scheme to monopolize and effective competition [existed] at both the seller and buyer levels," the arrangement, presumably, would be upheld "as a reasonable and lawful re-

3 Actually the extent of interterritorial competition will be a function of non-price elements of sale as well as of "price" more narrowly defined. Thus, the sentence might more accurately conclude, ". . . is able to demand in his own vicinity, and/or the cost of non-price values offered by one distributor falls below the cost of values that his neighbor must offer in his (the latter's) own territory."

4 The cost of invasion includes the expense of transporting the goods to the buyer's market (whether formally borne by seller or buyer) plus the expenses of exploring a less familiar and more distant territory (which may include the fruitless pursuit of new contacts and an increase in traveling expenses for salesmen).

5 Where a "pay-over" provision exists (see note 2 supra and accompanying text), the amount of the penalty will be another cost of invasion (see note 4 supra), and, as such, that much more of a barrier to competition, though not an insurmountable block.

626 Stat. 209 (1890), as amended, 15 U.S.C. $\$ 1$ (1958).

7 Such would seem to be the effect of court rulings. See United States v. Parke, Davis \& Co., 362 U.S. 29 (1960); A. C. Becken Co. v. Gemex Corp., 272 F.2d 1 (7th Cir. 1959); Englander Motors, Inc. v. Ford Motor Co., 267 F.2d 11 (6th Cir. 1959), criticized in Robinson, Providing for Orderly Marketing of Goods, 15 A.B.A. ANIITRUST SECTION 282, 312 (1959); Levi, The Parke, Davis-Colgate Doctrine: The Ban on Resale Price Maintenance, 1960 SuP. CT. Rev. 258. The Miller-Tydings Act, passed in 1937 as an amendment to $\S 1$ of the Sherman Act, exempts certain resale price maintenance agreements if they are made lawful in the state of resale by state law. 50 Stat. 693 (1937), 15 U.S.C. $\$ 1$ (1952). See the McGuire Bill, 66 Stat. 632 (1952), 15 U.S.C. \$45(a) (1952). 
straint of trade."3 But, remarkably, seventy-odd years of administering the Sherman Act have left only the faintest judicial guides for determining the legal status of closed territories. ${ }^{9}$ There are a few federal cases from before World War I, now of no more than academic interest. 10 Years ago the Federal Trade Commission seemingly approved closed territorial distributorships in a decision it rendered without opinion, and which it has since unceremoniously disowned.11 Operating under the judicial haze that surrounds closed territories, the Justice Department has been arguing that the practice is unlawful and has done so convincingly enough to garner a whole file full of consent decrees, especially since 1949.12 Bills have been proposed and congres-

8 Packard Motor Car Co. v. Webster Motor Car Co., 243 F.2d 418, 420 (D.C. Cir.), cert. denied, 355 U.S. 822 (1957). See Schwing Motor Co. v. Hudson Sales Corp., 138 F. Supp. 899 (D. Md.), aff'd per curiam, 239 F.2d 176 (4th Cir. 1956), cert. denied, 355 U.S. 823 (1957). See Day, Exclusive Territorial Arrangements Under the Antitrust Laws-A Reappraisal, 49 N.C.L. REv. 223 (1962), and Seitz, Exclusive Arrangements and the Refusal to Deal Problem, 11 VAND. L. REv. 85 (1957).

The Federal Trade Commission, in striking down a system of closed territorial distribution in Sandura Co., No. 7042, FTC, June 13, 1962, at 18, noted "respondent's objectives could be largely attained through . . . establishing exclusive distributorships with primaryresponsibility territories." Snap-on-Tools Corp., No. 7116, FTC Nov. 1, 1961, which the Commission cited at this point, seems, too, to have allowed that exclusive territories would be lawful. 3 Trade Reg. Rep. \15,546 at 20,413 (FTC 1961). Similarly, a number of Justice Department consent decrees prohibiting closed territories or customer allocation allow exclusive selling. See Day, supra, at 237 n. 47.

9 The Supreme Court has never passed upon the legality of closed territorial systems. The Eighth Circuit upheld such a system of restraint as early as 1903, Phillips v. Iola Portland Cement Co., 125 Fed. 593 (8th Cir. 1903), cert. denied, 192 U.S. 606 (1904), as did the Fifth Circuit in Cole Motor Car Co. v. Hurst, 228 Fed. 280 (5th Cir. 1915), (distinguishable on the grounds that the court found the distributor to be an agent, 228 Fed. at 284). In Boro Hall Corp. v. General Motors Corp., 124 F.2d 822 (2d Cir.), rehearing denied, 130 F.2d 196 (2d Cir. 1942), cert. denied, 317 U.S. 695 (1943), the Court upheld a limitation upon a used car dealer not to establish a showroom outside his "zone of influence"; there appear to have been no limitations upon the customers to whom he might sell, however. In United States v. Bausch \& Lomb Optical Co., 321 U.S. 707, 721 (1944), the Supreme Court stated that a seller "may not lawfully limit by agreement ... the price at which or the persons to whom its purchasers may resell" in the absence of state fair trade legislation. As for precedential value, however, Stanley Robinson has noted: "What the Court struck down was an intricate marketing system that was riddled with illegal price fixing agreements [in which] wholesalers had been limited to selling to retailers, and retailers to the public." Robinson, supra note 7, at 295 . To support his position that, standing alone, closed territorial restraints would not be controlled by Bausch \& Lomb, Robinson notes that Judge Rifkind, who wrote the opinion in the district court, 45 F. Supp. 387 (S.D.N.Y. 1942), did not even see fit to mention the case as pertinent in a later article. Division of Territories, How to COMPLY WTH THE ANTTRUST LAWs 127 (1954). See generally, Day, supra note 8; Jordan, Exclusive and Restricted Sales Areas Under the Anti-Trust Laws, 9 U.C.L.A.L. REv. 111 (1962); Comment, Restricted Channels of Distribution Under the Sherman Act, 75 HaRV. L. REV. 795 (1962).

10 See note 9 supra.

11 General Cigar Co., 16 F.T.C. 537 (1932). In Snap-On Tools Corp., 3 Trade Reg. REP. II 15,546, at 20,413 n.8 (FTC 1961), the General Cigar opinion is said to have "little precedential significance now."

12 See Day, supra note 8 , at 237 \& n.47. 
sional committees convened to consider writing into law special exemptions for practices which, so far as anyone knows, are not illegal.13 Now, finally, after many a feint and bluff, an authoritative courtroom showdown appears imminent. In a suit against one of the three largest manufacturers of heavy trucks, ${ }^{14}$ White Motor Co. v. United States ${ }^{15}$ which is docketed for argument before the Supreme Court this term, the Justice Department is contesting the legality of contracts whereby the manufacturer has granted its 200-odd distributors an "exclusive right" to sell within a defined territory, and provided further that the distributor shall not sell trucks "except to individuals, firms, or corporations having a place of business and/or purchasing headquarters in said territory." 16 A similar set of contracts is being challenged by the Federal Trade Commission in Sandura Co. v. FTC before the Sixth Circuit Court of Appeals this term.17 In preparing to hand down what promise to be the first authoritative decisions on closed territorial distribution, these courts will undoubtedly affect a significant portion of the nation's marketing economy.18

13 An account of some of the more recent legislative battles appears in Heuerman, Dealer Territorial Security and "Bootlegging" in the Auto Industry, 1962 WIs. L. REV. 486.

14 Between 1950, when its sales were $\$ 103$ million, and 1961, when its sales had risen to $\$ 334.5$ million, White had absorbed four competitors and captured $18 \%$ of the new truck registration in the heaviest classification listed by Commercial Car Journal $(33,001$ pounds and up) and $29 \%$ of the next heaviest category. In 1961, White, International Harvester, and Mack accounted for $65 \%$ of the registrations of new trucks 26,001 pounds and over. Commercial Car Journal, April, 1962, p. 75; Annual Report, The White Motor Company, 1961, p. 14; White Motor Company: A for Agility, Forbes, December 1, 1961, pp. 19-23.

15194 F. Supp. 562 (N.D. Ohio 1961); prob. juris. noted, 369 U.S. 858 (1962).

16194 F. Supp. at 568.

17 Commission decision reported at No. 7042 FTC June 13, 1962.

${ }_{18}$ The Supreme Court will be pressed, but will not necessarily be compelled to decide whether closed territorial distribution is per se unlawful; the district court that tried the case below found a conspiracy between White and its distributors to fix resale prices and to allocate customers between itself and its distributors (White "reserved" certain choice accounts to which it sold directly), as well as to allocate territories in the manner discussed in this article. United States v. White Motor Co., 194 F. Supp. 562, 586 (N.D. Ohio 1961). Conceivably, the Supreme Court could sustain the final judgment's prohibition on further allocation of territories (Final Judgment, Paragraph VI, Sept. 5, 1961, unreported) on the grounds that the vertical allocation of territories was "part and parcel" of an unlawful scheme to maintain resale prices and reserve judgment as to whether the allocation would be unlawful per se if it existed by itself. The Commission, in Sandura, said it was not "compelled to reach" the question of per se unlawfulness (see note 58 infra), but it may not be easy for subsequent respondents to erect a more favorable defense than Sandura did. See text accompanying notes $31-56$ infra.

It is interesting to note that insofar as White "reserved" customers to distribute to direct$1 y$, it relinquishes any claim to paternal concern for its distributors' well-being, such as it might advance in the instance of dividing territories solely between the distributors. In reserving customers, White steps down from the manufacturing to the distributing line of commerce, and, hence, its actions must be judged as an ordinary horizontal division of territories, doctrinally indistinguishable from the unlawful scheme of United States v. Addyston Pipe \& Steel Co., 175 U.S. 211 (1889); see text accompanying notes 59-69 infra. White's claim 
II.

At a time when the law of resale price maintenance was still being staked out, Mr. Justice Brandeis, never a warm admirer of antitrust law as he saw it developing,19 complained: "Whether a producer of goods should be permitted to fix by contract . . . the price at which the purchaser may resell them, and if so, under what conditions, is an economic question. To decide it wisely it is necessary to consider the relevant facts, industrial and commercial, rather than established legal principles."'20

His plea for an enlightened economic analysis was to no avail. Whether for better or for worse, in two of the decisions that ultimately proved most influential in fashioning the course the law was to take, what held sway was a quaint and very established legal principle about restraints on alienation of chattels, taken from Coke upon Littleton. 21

The occasion for recalling this fragment of history is the docketing of the White and Sandura cases, for the arguments which have shaped up about them, both pro and con closed territories, threaten to take the courts off on no more direct a route to decision. Primarily, the government is arguing (1) that since resale price maintenance is unlawful per se, and it restrains but one aspect of intrabrand competition, a fortiori closed territories ought to be equally unlawful since they preclude rivalry in non-price aspects of competition as well;22 and (2) that since the distributors could not have divided terri-

in its brief before the district court was that "the White Motor Company cannot fairly bid against its own distributors ... . and the distributors . . . cannot compete . . . with the manufacturers of other makes of trucks ...." in bids for sales to governmental units. Brief of the Defendant in Opposition to Plaintiff's Motion for Summary Judgment, p. 37. But if the distributors truly had no chance to be low bidders on certain sales, why would it be necessary, by contract, to prohibit them from trying? More likely, reserved accounts were lucrative enough that even as second sellers the distributors might profitably threaten the bidding of the manufacturers.

19 See Comment, Mr. Justice Brandeis, Competition and Smallness: A Dilemma Reexamined, 66 YALE L.J. 69 (1956).

20 Boston Store v. American Graphaphone Co., 246 U.S. 8, 27 (1918) (concurring opinion).

21 Lurton, J., in Park v. Hartman, 153 Fed. 24, 39 (6th Cir. 1907), and Hughes, J., in Dr. Miles Medical Co. v. John D. Park \& Sons Co., 220 U.S. 373, 404 (1911), both pointed to Coke on Littleton $\S 360$ : "If a man be possessed of a horse or any other chattel real or personal, and give his whole interest or property therein, upon condition that the donee or vendee shall not alien the same, the same is void, because his whole interest and property is out of him so as he hath no possibility of reverter; and it is against trade and traffic and bargaining and contracting between man and man." See Chaffee, Equitable Servitudes on Chattels, 41 HARv. L. Rev. 945, 980-82 (1928); Levi, supra note 7, at 274-75.

22 Brief in Support of the Plaintiff's Motion for Summary Judgment, p. 12, United States v. White Motor Co., 194 F. Supp. 562 (N.D. Ohio 1961). This is referred to as "plaintiff's major and direct proposition" in Plaintiff's Brief in Reply, p. 1. The argument, which also appears in Proposed Findings by Counsel Supporting the Complaint, p. 122, Sandura Co., No. 7042, FTC, Sept. 15, 1961, may have been suggested by Judge Rifkind in Division of Territories, How to CoMpLY WTTH THE ANTrTRUST LAws 127, 132 (1954).

Of course, no less than with resale price maintenance, the defendant's contracts could be 
tories among themselves (hence, a horizontal allocation of territories presumably unlawful under Addyston Pipe $)^{23}$ they should be able to fare no better merely because the division is effected vertically, by a series of independent contracts executed through the manufacturer. 24 The defense, for its part, is relying heavily upon the some-time defense of ancillary restraint, which has the virtue of being eighteenth century in origin, but which is probably inapposite to closed territorial distribution. 25 Also, since the rule of reason has

struck down on the basis of the same reasoning advanced by Coke; for White to give its "whole interest and property" in its trucks and still seek a measure of control over their movement is no less susceptible of labelling "against trade and traffic and bargaining and contracting between man and man." See note 21 supra. But see note 74 infra.

23 United States v. Addyston Pipe \& Steel Co., 175 U.S. 211 (1899), affirming 85 Fed. 271 (6th Cir. 1898). See notes 59-69 infra and accompanying text.

${ }^{24}$ Brief in Support of the Plaintiff's Motion for a Summary Judgment, p. 13, United States v. White Motor Co., 194 F. Supp. 562 (N.D. Ohio 1961). The argument appeared in a charge to a jury in Loewe Supply Co. v. Weed Chain Tire Grip Co., TRADE CAS. $\pi 5506$ (S.D.N.Y. 1917). See note 71 infra and accompanying text.

25 The doctrine of ancillarity is supposed to have originated in the case of Mitchell v. Reynolds, 1 P. Wms. 181, 24 E.R. 347 (1711). See Bork, Ancillary Restraints and the Sherman Act, 15 A.B.A. ANIrTRUst Section 211, 212 (1959). In American law, the most celebrated discussion of the doctrine is by Judge Taft in United States v. Addyston Pipe \& Steel Co., 85 Fed. 271 (6th Cir. 1898), aff'd, 175 U.S. 211 (1899). In surveying precedent, Judge Taft recognized that certain contracts that arguably restrained trade had been enforced notwithstanding, all of which restraints might have been vaguely characterized as "merely ancillary to the main purpose of a lawful contract, and necessary to protect the covenantee. ..." 85 Fed. at 282 . Judge Taft did not state the converse, viz., that all restraints "merely ancillary" were therefore lawful. $C f$. 85 Fed. at 281-82. Of the actual exceptions from which the generalization relied upon was made, that most nearly in point is "... covenants .... (4) by the buyer of property not to use the same in competition with the business retained by the seller." Id. at 281. But the cases on which this statement was based, and the principle for which it has come to stand, are hardly broad enough to tuck under the mantle of ancillary cases in which a continuing manufacturer of goods limits his distributors from competing among themselves. What the exception was and is understood to mean is pointed up in Dr. Miles Medical Co. v. John D. Park \& Son Co., 220 U.S. 373 (1911), where the Court rejected the doctrine of ancillarity offered as a defense of resale price maintenance. "The present case is not analogous to that of a sale of good will, or of an interest in a business, or of the grant of a right to use a process of manufacture. The [producer] has not parted with any interest in its business or instrumentalities of production. It has conferred no right by virtue of which purchasers of its product may compete with it. . . . Nor are we dealing with a single transaction, conceivably unrelated to the public interest." Id. at 407

Without acknowledging this particular passage, Robinson, supra note 7, argues to extend ancillarity to cover vertical allocations of territory because he sees a "close parallel" between cases in which the seller of a steamship makes the vendee promise not to operate on the vendor's coast, Oregon Steam Nav. Co. v. Winsor, 87 U.S. 64 (1873), and "a territorial restriction in a sale of goods by a manufacturer who does his own wholesaling or retailing in the reserved area." Robinson, supra at 292. But even if the steamship case is still good law, as is indicated by Tri-Continental Fin. Corp. v. Tropical Marine Enterprises, Inc., 265 F.2d 619 (5th Cir. 1959), but see Bork, supra at 219, such a case as that Robinson suggests as an analogue to it would seem to be a horizontal allocation of territories, thus quite likely per se unlawful under Addyston Pipe. See note 16 supra. (United States v. Bausch \& Lomb Optical Co., 45 F. Supp. 387 (S.D.N.Y. 1942), aff'd as modified, 321 U.S. 707 (1944), is distinguishable in that $A$ manufactured lenses exclusively for $B$, and convenanted not to compete with $B$ in their distribution; but this seems to have entailed $A$ 's abstaining from distributing lenses altogether in the United States (see 45 F. Supp. at $391 \& 398$ ), and not 
been accorded to exclusive territories, the defense maintains that no violence would be done to the administration of justice if each closed territorial distribution pattern enjoyed a similar day in court, to screen out and weigh the competitive implications it holds for the market to which it is relevant. 26

Indeed, if the Court feels inclined to fall back upon holdings in related areas as a springborad to their decisions, they might equally well analogize closed territories to boycotts, 27 restraints imposed upon an agent, 28 "conscious parallelism," 29 or vertical integration. 30 All such arguments, however,

$A$ 's dividing distribution markets between itself and $B$.) If so, this would seem to moot the importance of the next question in Robinson's argument: "Does it make any difference if the manufacturer elects not to perform any part of the wholesaling or retailing functions himself but to rely on several independent distributors?" Robinson, supra at 292.

${ }^{26}$ See Brief for Respondent, pp. 8, 33-34, Sandura Co., No. 7042, FTC June 13, 1962; Brief for Defendant, pp. 10-29, United States v. White Motor Co. 194 F. Supp. 562 (N.D. Ohio 1961). At times exclusive and closed cases seem to be run together indiscriminately. In Sandura, Commissioner Elman distinguished the exclusive territorial cases away in a footnote. Sandura Co., supra at 23 n.10.

27 If territories are divided among distributors $A, B, C$ and $D$, from the point of view of buyer $a$ in $A$ 's territory, the agreement might appear to be a boycott of his wants by $B, C$ and $D$. So construed, the arrangement might be an unlawful boycott. $C f$. Klor's, Inc. v. Broadway-Hale Stores, Inc., 359 U.S. 207 (1959). Robinson acknowledges the possibility of such an argument, allowing that it might be valid upon certain factual determinations but, as a general rule of application finds it "quite strained." Robinson, Providing for Orderly Marketing of Goods, 15 A.B.A. AntrTRust Section 282, 302-03 \& n.94 (1959). Cf. Levi, The Parke, Davis-Colgate Doctrine: The Ban on Resale Price Maintenance, 1960 SuP. CT. REv. 258, 269-70 ("The revelance of the law of boycott, or of collective refusals to deal, to resale price maintenance is close.")

${ }^{28}$ As early as 1915 it appears that the Fifth Circuit validated a vertical division of territories upon a finding that the distributor was an agent, Cole Motor Car Co. v. Hurst, 228 Fed. 280, 284 (5th Cir. 1915). Citing United States v. General Elec. Co., 272 U.S. 476 (1926) (a manufacturer's establishing the resale price at which a bona fide agent is to vend the manufacturer's article is not unlawful), White's counsel argued: "Yet as far as restraints on competition or trade and commerce are concerned, there are indisputably no more restraints ... caused by the defendant's marketing of its products through distributors and dealers operating under contracts such as those involved in the case at issue than there would be if the defendant had marketed its products through bona fide agents whose agreements with their employer contained the same provisions which are complained of by the plaintiff in the instant case." Brief for Defendant, p. 68, United States v. White Motor Co., 194 F. Supp. 562 (N.D. Ohio 1961).

29 Because each distributor, in individually contracting with the manufacturer not to sell beyond his assigned territory, was presumably aware of similar provisions in contracts executed between other distributors and the manufacturer, a horizontal agreement to divide the territory might have been imputed to the distributors even in the absence of an express agreement. $C f$. Interstate Circuit, Inc. v. United States, 306 U.S. 208 (1939); Eastern States Retail Lumber Dealers' Ass'n v. United States, 234 U.S. 600 (1914); FTC v. Cement Institute, 333 U.S. 683, $716 \mathrm{n} .17$ (1948) ("It is enough to warrant a finding of 'combination' within the meaning of the Sherman Act, if there is evidence that persons with knowledge

[Footnote 29 continued on p. 293]

30 Because closing territories may be a less anticompetitive measure than were the manufacturer to integrate forward by merger, and because a rule of reason is applied to mergers, it might be argued that a fortiori a rule of reason ought to apply to the closing of territories. See Day, supra note 8, 249-50 (1962); note 131 infra. 
only tend to perpetuate doctrine that may not have been especially well examined at birth; and those whose interests lie in the balance could feel they deserve that the "economic question" be sought out and answered.

\section{III.}

During the period following World War II, the Sandura Company, which had been manufacturing floor covering since 1923, developed a new type of vinyl floor covering known as rotary-vinyl or roto-vinyl. 31 Sandura patented a process by which it could print a design on specially manufactured paper sheet by the same rotogravure process that is used by newspaper supplements; a vinyl plastic is then poured upon the sheet and bonded to a felt base. 32 The result, which seems to have been a significant step forward in the floor cover-

\section{[Footnote 29 continued]}

that concerted action was contemplated and invited, give adherence to and then participate in a scheme.").

The Government did not pursue this line of argument before the district court in the White case, insofar as appears from its briefs. One reason for the omission may have been that no court would have wished to impute a conspiracy without an elaborate investigation of the distributors' courses of conduct, $c f$. Theatre Enterprises, Inc. v. Paramount Film Distrib. Corp., 346 U.S. 537, 540-41 (1954), and it would thus have been an unwise theory to advance in a motion for summary judgment.

Perhaps also, to have framed the issue in this manner would have faced the courts with deciding whether, in fact, an outright horizontal agreement among White's distributors would have been unlawful per se. True, White's distributors are each a potential competitor of the others, and a number of cases from Addyston Pipe to the present have lent themselves to the proposition that a division of territories among competitors is per se unlawful; but the facts of Addyston Pipe (See notes 59-69, infra and accompanying text), viz. two-thirds control of the market, demanded no such resolution. The cases that have followed in its wake also seem to be set in the context of powerful manufacturers, if not of international cartels, and the division of territories is often complicated by independent violations of law. See Timkin Roller Bearing Co. v. United States, 341 U.S. 593 (1951); United States v. United States Alkalai Export Ass'n, 86 F. Supp. 59 (S.D.N.Y. 1949); United States v. National Lead Co., 63 F. Supp. 513 (S.D.N.Y. 1945), aff'd 332 U.S. 319 (1947); United States v. General Dyestuff Corp., 57 F. Supp. 642 (S.D.N.Y. 1944). Johnson v. Joseph Schlitz Brewing Co., 33 F. Supp. 176 (E.D. Tenn. 1940), aff'd, 123 F.2d 1016 (6th Cir. 1941) was undoubtedly of humbler international impact, but defendants Schlitz, Anheuser-Busch, Inc. and Pabst probably controlled a significant percentage of the relevant Chattanooga or Tennessee markets. (See also United States v. Bausch \& Lomb Optical Co., 321 U.S. 707 (1944) discussed in notes 9 and 25 supra.) Perhaps the government attorneys were not as certain as some commentators that the professed per se unlawfulness of horizontal divisions would stand up in fact situations more favorable to the defense than those presented in cases of record. In a favorable factual setting, two recent decisions have questioned the supposedly sacrosanct rule that tying arrangements are per se unlawful, Dehydrating Process Co. v. A. O. Smith Corp., 292 F.2d 653 (1st Cir.), cert. denied, 368 U.S. 931 (1961); United States v. Jarrold Electronics Corp., 187 F. Supp. 545 (E.D. Pa. 1960), aff'd, 365 U.S. 567 (1961); and a tendency towards greater flexibility of the per se rule may be manifesting itself already in the area of division of territories. See United States v. Pan American World Airways, Inc., 193 F. Supp. 18 (S.D.N.Y. 1961), rev'd on other grounds, Jan. 14, 1963, 31 U.S. L. Week 4124 (U.S. Jan. 22, 1963). Dennison Mattress Factory v. The Spring-Air Co., 308 F.2d 403 (5th Cir. 1962).

31 Sandura Co., No. 7042, FTC, Initial Decision at 3, Sept. 15, 1961.

32 Transcript, pp. 57-59. 
ing industry, Sandura marketed under the name "Sandran." Once in the market, Sandran and Crown Vinyl, its premium quality counterpart, face a broad range of rival products. In one sense, the competitive arena is the whole floor covering industry which, in general, is divided into resilient hard surface and soft surface floor coverings, the latter including rugs, carpets and mats made from wool, cotton and other fibers. ${ }^{33}$ Of the various sorts of hard surface floor coverings with which Sandura must compete, enamel surface, felt base floor coverings are in the cheapest category, with asphalt tile, rubber tile and high.grade calandared vinyls at the most expensive end of the price spectrum; the price of Sandran, like that of linoleums, falls somewhere in between. ${ }^{34}$ The hard surface floor covering industry is dominated by three "integrated full-line giants" 35 who possess between 77 per cent and 84 per cent of industry assets. The sales of Sandura, which is about the twentieth or twentyfifth largest firm in the industry, ranged from 1.1 per cent in 1954 to 4.8 per cent in 1958.36

In the 1930's, when Sandura's sales were limited to old fashioned enamel surface "felt base," the company had an "exclusive territory" plan. In contrast to the practices of its larger competitors, who may have had as many as two or three distributors in a single city, no city had more than one Sandura distributor. "Felt base" being a heavy product at the low end of the floor covering price scale, the distributors' cities were far enough apart that, in practical effect, each Sandura distributor seems to have been unhampered by competition with any other Sandura distributor. 37 In 1949, however, with

33 Soft-surface floor coverings seem to be regarded by consumers as acceptable substitutes in many cases. The Atlanta, Georgia, distributor of Sandran complained that tufted carpeting was impinging on his sales, Dalton, Georgia, being perhaps the largest tufted carpeting manufacturing center in the world. Transcript 1390-91. These rugs retail at $\$ 19.95$ for a $9^{\prime} \times 12^{\prime}$ rug, i.e., at $\$ 1.66$ per sq. yd., compared with Sandran's $\$ 1.39$. Ibid. The California distributor noted that grass rugs and cheap carpeting-especially in new apartment units-have had a pronounced effect on hard-surface coverings in the Southern California market. Id. at 1539.

34 Sandura Co. No. 7042, FTC, Initial Decision at 4, Sept. 15, 1961, and see Proposed Findings by Counsel Supporting the Complaint, p. 9.

35 Id., Opinion of the Commission, at 17. The reference is to Armstrong Cork, Congoleum-Nairn and Pabco. See Id., Initial Decision, at 4.

${ }^{36} \mathrm{Id}$., Opinion of the Commission, at 17, and Initial Decision, at 4. From the author's interviews with floor covering distributors, it would appear that these market figures, based upon all hard-surface sales, are far more favorable to Sandura than the Commission could have allowed had it felt that a market power test was relevant. Distributors tend to break the market down into tile goods, cemented roll goods and loose lay roll goods. The last class, comprising roto-vinyls and felt base, seems to be bought by people who do not own their quarters and cannot make permanent alterations or who, for some reason or another, are not especially interested in permanency. Moreover, even where the price of loose lay goods may make them appear comparable buys with other floor coverings, store prices are misleading in the light of the different installation expenses involved, e.g., $\$ 1.39$ Sandran may be installed for something like $\$ 0.30$ per square yard in areas in which $\$ 1.69$ light-gauge linoleum costs $\$ 1.00$ per square yard to install.

37 Id., Initial Decision, at 5-6; see Proposed Findings by Counsel Supporting the Complaint, p. 18. 
expectations of considerable consumer demand for its revolutionary new "Sandran," markets previously exclusive were thrown open to new distributors. For example, Philadelphia came to have three distributors, and New York, Chicago and Detroit each had two. ${ }^{38}$

Sandura's experiment with unbounded multiple distributorships was to prove short-lived. The distribution pattern which followed seems to have been precipitated, in the first instance, by two defects which Sandran had when it was introduced into the market. ${ }^{39}$ These were finally remedied in 1953 , but only after a period of pronounced dealer and consumer dissatisfaction during which the company's sales revenue was nearly halved in three years. ${ }^{40}$ In 1953, Sandura instituted the first change in its distribution pattern; it began giving franchises to select retail dealers and permitted its distributors to resell its products only through such dealers. 41 Nevertheless, in 1954 and 1955 Sandura was neither able to meet its bank obligations nor those owed to some of its raw material suppliers.42 It was indebted to its own distributors as a result of a 1954 price reduction, since it was under an obligation to reimburse distributors for the differences in price on existing stock of merchandise. Because it

38 Id., Initial Decision, at 5.

${ }^{39}$ One of the defects was that Sandran turned yellow in the traffic area, a failure that was not cured until 1951. More serious was the tendency for delamination to occur between the paper and the felt backing, with the result that the paper would slide a little along the backing. No sooner had Sandura discovered that this "cold flow" could be cured by changing the laminating adhesive from asphalt to rubber than rubber went on allocation as a result of the Korean War. Another adhesive was found, but it tended to crystallize on aging, with the result that after Sandran had been on the floor for anywhere up to a year there was a complete separation of layers. Brief for Respondent, Sandura Co., No. 7042, FTC, June 13, 1962; and see, Id., Initial Decision at 4.

${ }^{40}$ Transcript 310-11; Sandura Co., No. 742, FTC, at 3. Sept. 15, 1961.

Sandura's sales, in thousands of dollars, seem to reflect the marketing difficulties which were engendered by these early product defects:

$\begin{array}{lr}1950 \text { (Year after introduction of Sandran) } & \$ 7,126 \\ 1951 \text { (Yellowing cured) } & 4,427 \\ 1952 & 5,353 \\ 1953 \text { ("Cold flow" finally remedied; dealer } & \\ 1954 \quad \text { franchise plan put into effect) } & 3,842 \\ 1955 \text { (Distributorships begin to be closed) } & 3,557 \\ 1956 \text { (Closure "substantially completed" by } & 4,763 \\ 1 & \\ 1957 \text { middle of this year) } & 8,673 \\ 1958 \text { (11,827 } \\ 1959 \text { 1960 } & 19,663 \\ 1961 & 24,001 \\ & 16,894 \\ & 13,687\end{array}$

Market figure sources: MOODY's INDUSTRIALS 1470 (1962); MOODY's INDUSTRIAL MANUAL 776 (1961).

41 Sandura Co., No. 7042, FTC, Initial Decision, at 4, Sept. 15, 1962.

42 Which suppliers included some of its own competitors. Transcript 1571, 1574-78. Respondent's Exhibits Nos. 37, 38. 
could not meet the amounts due, it had to request the distributors to extend the time for payment up to one year.43 Moreover, Sandura requested distributors not to sell defective merchandise, in order not further to degrade the Sandran reputation. As a result, distributors were being paid off at the rate of 30,000 dollars a month for quarantined merchandise. 44 In its brief before the full Commission, Sandura is described as, in 1955, de facto bankrupt.45 The industry was aware of this, 46 and its larger creditors proposed that it should be merged into one of its competitors. 47 To compound its economic adversities, Sandura was unable to finance any national advertising program; there simply was no money available for advertising in 1951,1952 or 1953.48 Lacking capital for advertising and warehousing made it impossible to market directly to retailers, and Sandura's shaky history was not particularly attractive to the established wholesaler, who wanted a floor covering with wide public acceptance, backed by extensive national advertising. 49 Another impediment to a distributor's taking on the Sandura line was the fact that it had only two products to offer while Armstrong, for example, could offer its distributors as many as twelve different items. ${ }^{50}$ Sandura's sales manager testified: "[We] were in a position where the distributor who could handle our line and pay his bills, who was a floor covering distributor, knew the market, was not interested in us; we had nothing to offer him that he didn't already have ...."51

In 1955 , seemingly faced with extinction Sandura instituted a program whereby each distributor would end up not only as the sole outlet in the city in which its warehouse was located, but also as the sole outlet in a specified territory surrounding it, from which other distributors were barred from making sales. 52 Such territories were to be known as "closed territories" as distinguished from the "exclusive territories" of the 1930's. Between 1955 and 1959 its sales climbed from $4,763,000$ dollars to $24,000,000$ dollars. 53

Called before the FTC on charges that its distributorship program violated section 5 of the Federal Trade Commission Act, 54 Sandura argued that its closed territories neither constituted an unreasonable restraint on competi-

43 Transcript 1203-05, 1289, 1422.

45 Sandura claimed past-due obligations in excess of $\$ 1$ million. Mortgage liens on real estate and machinery totalled another $\$ 331,000$. Respondent's Exhibits Nos. 37 A \& B.

46 Transcript 1613. ${ }^{47} \mathrm{Id}$. at $1578-79$. 1962.

48 Id. at 1232; see Brief for Respondent, p. 17, Sandura Co., No. 7042, FTC, June 13

49 See Transcript 1542-43, 1649-50, 1661-62, 1699-1700, 2112, 1193-95; Brief for Respondent, supra note 48 , pp. $15,18$.

50 Transcript 1169-70, 1659-60.

51 Id. at $1166-67$.

52 Sandura Co., No. 7042, FTC, Initial Decision at 16, 18, Sept. 15, 1961. New York and Philadelphia retained multiple distributorships.

53 See note 40 supra.

5466 Stat. 632 (1952) as amended 72 Stat. 809, 1750 (1958), 15 U.S.C. 45(a) (1958). 
tion nor tended towards monopoly and, rather than being an indivisible part of an illegal price fixing scheme, served valid business purposes.55 An FTC hearing examiner agreed that "there [had] been no lessening of competition in the industry as a whole as the result of" Sandura's distribution program. 56 Nonetheless, the examiner considered them a per se violation of the Act.57 The Commission, in upholding, did not feel "compelled to reach" the soundness of so disposing of the problem, Sandura's plan being "clearly unlawful" on its facts. 58

\section{IV.}

"Clearly unlawful" certainly could characterize the plan struck upon in the 1890 's by certain manufacturers of cast iron pipe, whatever area there might be for debate in Sandura. As the facts are preserved in United States $v$. Addyston Pipe \& Steel Co.59 the six defendant pipe manufacturers accounted for some two-thirds of the output of iron pipe in a significant portion of the United States. 60 This potential market power was augmented by the fact that the transportation costs of large manufacturers outside this territory amounted to two to six dollars per ton, 61 figures which represented as much as one-third the fair market value of the pipe.62 As a result, while, for example, the defendant Chattanooga foundry could have furnished pipe to St. Louis at seventeen or eighteen dollars per ton and made some profit, 63 it could have raised its price even to twenty-three or twenty-four dollars before it would have had to fear competition by one of the large pipe foundries of New York, Eastern Pennsylvania or New Jersey. 64 On the other hand, so long as effective competition prevailed and bidding among the geographical "insiders" was

s5 Brief for Respondents, p. 8, Sandura Co., No. 7042, FTC, June 13, 1962.

56 Sandura Co., No. 7042, FTC, Initial Decision at 32, Sept. 15, 1961.

$57 \mathrm{Id}$. at 35-36. Examiner John Lewis went on to conclude that "in any event, even if the so-called rule of reason were deemed to apply to vertical combinations solely involving territorial restrictions, there can be no doubt that where such a combination is used to fix or control prices it is illegal per se." Id. at 41.

58 Id. Opinion of the Commission at 21 (Elman, Commissioner). Commissioner Elman noted that Sandura netted \$355,313 in 1960 and $\$ 352,874$ in 1961, and was able, in 1957-58, to invest approximately $\$ 1,300,000$ in new plant facilities and $\$ 800,000$ in new warehouse space, facts that "hardly portend imminent financial doom." Id. at 15. He doubted that Sandura had proven a "causal relationship" between closed territories and Sandura's remarkable change of fortunes (id. at 16), and concluded that the closed territorial plan "prejudices the public by preventing competitive considerations of price, service and the like from playing their normal part in distributor-dealer relationships, and it exceeds 'what is fairly necessary' for the furtherance of respondent's objective of erecting a strong, vigorous distribution system for marketing its goods." Id. at 23.

s9 175 U.S. 211 (1899), affirming 85 Fed. 271 (6th Cir. 1898).

6085 Fed. at 292, 301.

62 See $i d$. at 275.

or Id. at 277.

$63 \mathrm{Ibid}$.

${ }^{64}$ Adding $\$ 6$ to $\$ 17$ and to $\$ 18$. Indeed, the fixed price for St. Louis appears to have been exactly \$24. Ibid. 
unrestrained, long before Chattanooga (or any other defendant) had raised its St. Louis price to twenty-three or twenty-four dollars, there remained at least five other manufacturers who would have entered the bidding and creamed off enough sales to force the price leader to withdraw his demands to the competitive level. In such manner, bidding among themselves prevented the defendants from raising prices so as to realize the territorial advantage they held, collectively, over outside interests. Furthermore, trying to underbid one another each time a fresh order appeared on the market probably reduced the general profit level per sale without an offsetting increase in the tonnage of pipe sold.

To avoid the mutually disadvantageous effects of competing among themselves, certain cities were "reserved" to certain manufacturers, from which the other manufacturers party to the agreement would not entertain bids in good faith.65 Each producer could then charge a price in "his" territory which would be limited only by what the market for iron pipe would bear, ${ }^{66}$ and by the transportation expenses of geographical outsiders. ${ }^{67} \mathrm{Or}$, transferred into terms of impact on the consumer, one may assume that these six competitors would not each have withdrawn from five-sixths of his potential market unless each estimated that he could make more profit in the one-sixth that he retained than he was earning across the total territory prior to the agreement. Aside from possible economies in the cost of sale, the only way the same territory could support the same number of manufacturers, all earning more than before, is by the public in each of the six subdivisions being burdened with a higher price than it had been paying. It can be shown, too, that the quantity of the product offered the public will diminish after the agreement.68 These consequences, and the resulting misallocation of resources, 69 would seem to constitute the gravamen of any complaint against competitors dividing territories.

${ }^{65} \mathrm{Ibid}$. The facts in the text represent only a portion of the scheme for which the defendants were charged.

${ }^{66}$ As an ideal, he will seek to operate at the output where marginal cost equals marginal revenue; his actual pricing decisions will probably take into account a number of long range considerations, such as discouraging the entry of potential competitors. STIGLER, THE THEORY OF PRICE 210-13 (rev. ed. 1952).

${ }^{67}$ See text accompanying notes 61-62 supra. Of course, the local mills that were not parties to the conspiracy probably also exerted some restraining influence. The annual capacities of all the relevant mills are set out 85 Fed. at 277.

68 Given the same demand curve for the product before and after the division of territories, the increase in price might as well be viewed as a withdrawing of product from the market. This fairly fundamental observation is pointed out here in the text for purposes of contrast, below, with a vertical division of territories; for where a single manufacturer divides territory among his distributors, it may be in return for increased selling efforts by virtue of which the brand's output will be increased even though the price of the product rises.

69 Professor Stigler deems worthy of "laymen and sophomores" the criticism of monopolies that they restrict output and raise prices, STIGLER, op. cit. supra note 66, at 213, 
$\mathrm{V}$.

Assuming upon the authority of Addyston Pipe that a division of territories among competitors would be unlawful per se, both the district judge who tried the White case and the FTC hearing examiner in Sandura were attracted by the same passage from the 1911 Supreme Court decision in Dr. Miles Medical Co. v. John D. Park \& Sons, Co.70 There, faced with the validity of a vertical agreement between a manufacturer and his dealer to maintain resale prices, the Court had extrapolated from the established illegality of horizontal price fixing to state, "the [manufacturer] can fare no better with its plan of identical contracts than could the dealers themselves if they formed a combination and endeavoured to establish the same restrictions, and thus achieve the same result, by agreement with each other."'71

Indeed, if one starts with the premise that it is literally unlawful per se for competitors to allocate the market among themselves, 72 illegality would attach no less to competitors who were selling the same brand than to those selling competing brands, just as it should not matter that the brand the conspirators sold commanded only a small share of the market. All of a manufacturer's distributors are, in fact, potential economic rivals who undoubtedly see in their contracts with the manufacturer "the same result"73insulation from competition-that they might have wished to achieve by agreement with each other. On the other hand, the fact that the "agreement" was effectuated not inter se, but through independent vertical contracts between the manufacturer and each distributor, carries with it some economic consequences which may cast doubt upon the propriety of invoking the per se rule. ${ }^{74}$ Essentially, these considerations are suggested by the fact that the very

and reformulates the objection: "under monopoly the allocation of resources is inefficient.' Id. at 213-14.

70220 U.S. 373 (1911).

71 Id. at 408, cited in 194 F. Supp. at 585 and Sandura Co., No. 7042, FTC, Initial Decision, at 35, Sept. 15, 1961.

72 One may, however, question either whether anything is literally per se unlawful; see Montague, "Per Se Illegality" and the Rule of Reason, 12 A.B.A. SECTION ANTTIRUST 69 (1958), or even whether division of territories is within this class, if it exists. See United States v. Pan American World Airways, Inc., 193 F. Supp. 18 (S.D.N.Y. 1961), rev'd on other grounds, Jan. 14, 196331 U.S.L. Week 4124 (U.S. Jan 22, 1963); Dennison Mattress Factory v. The Spring Air Co., 308 F.2d 403 (5th Cir. 1962).

73 See 194 F. Supp. at 585.

${ }^{74}$ Dean Levi, in analyzing resale price maintenance, points up a possible doctrinal limitation upon making the same jump. Noting that "fatal restriction on alienation is in the background of the resale price cases," Levi, The Parke, Davis-Colgate Doctrine: The Ban on Resale Price Maintenance, 1960 Sur. CT. REv. 258, 275 (compare note 21 supra), he suggests that "the argument impliedly distinguishes vertical price understandings from horizontal price arrangements. ... It suggests that understandings unlawful as agreements fixing prices when made horizontally need not be considered unlawful, though unenforceable, when made vertically. The justification would be that vertical price arrangements are really not 
advantages the distributors may see in a division of territories-the opportunity to levy non-competitive resale prices-appear to be inimical to the manufacturer.

Viewed from the standpoint of the manufacturer, once he has decided to part with his goods at $\mathrm{X}$ dollars each, he appears to have nothing to lose and everything to gain by his resellers pressing to outdo one another with lower prices, higher promotional outlays and broader services. The manufacturer has nothing to lose because the costs of such competition must be struck from the distributors' margins of profit, not the manufacturer's (who will gross $X$ dollars per unit whatever the ultimate consumer pays);75 he has everything to gain because the more the rivaling distributors offer in promotion and services and the lower their final price, the more quickly will the public buy up the original order, the sooner will the distributors turn back to him with fresh requests to replenish their stores, and the more likely is the public to develop a permanent preference for his product.

Conversely, by insulating each of the distributors from the price levelling effects of competition, a manufacturer would appear at the same time to submit to a certain restriction of his output per unit of distributor investment; that is, if a manufacturer opened territories and there did not result a net withdrawal of resources the distributors were willing to invest in the promotion of his product, it might be expected that the resale price would go down and output would increase. 76 The fact that some manufacturers close territories notwithstanding suggests that the quid pro quo of closure may be the receipt of distributor investment and services otherwise unachievable, which might maximize sales over and above open distributorships by increasing the total selling services 77 placed at the manufacturer's disposal. If so, rather than ineluctably to limit the manufacturer's output (as appears to be the case with horizontal agreements), 78 the vertical arrangements may actually have been aimed at increasing output as much as possible under the circumstances of the manufacturer's market position. Thus, a manufacturer who has closed territories has not renounced rivalry with his competitors but is acting consistently with an aim to augment his own market share. Also, the interests of manufacturer and distributors being somewhat opposed as they divide between them the product's earning power, the manufacturer's hand in the contracts

price fixing, and not unreasonable restraints of trade, unless there is evidence of such widespread effects as to have the same general consequences as horizontal arrangements among the buyers setting a general market price." Id. at 277.

75 Of course, the closing of his territories may influence the charge per unit to his distributors, a possibility explored below.

76 See note 68 supra and accompanying text.

77 Including salesman hours, floor space, advertising outlay influencing customers toward the manufacturer's brand rather than toward another's, etc.

${ }^{78}$ See notes 65-69 supra and accompanying text. 
may influence the long-term consequences of a vertical allocation of territories differently than had it been the dealers who "endeavoured to establish the same restrictions... by agreement with each other."79 If it is true that, ideally, a manufacturer shares something of the public's interest in his distributors competing, it may be that if his bargaining power vis-à-vis his distributors increases he will wrest away the territorial boundaries himself. There also arises the possibility that if the courts should remove the territorial security before the manufacturer reaches this stage of market power his position might deteriorate enough to reduce the general quality of competition in the market in which he operates. These possibilities would seem to require further analysis of the benefits a manufacturer seeks from closing territories, before extrapolating from the per se illegality of horizontal allocations of territory to condemn similar, but vertical, arrangements.

\section{VI.}

The facts of Sandura suggest the possibility of situations in which but for the available recourse to closed territorial distribution a manufacturer would be unable to attract (or retain) the number of qualified distributors necessary to sustain his product in competition. In this regard the history of Sandura is particularly interesting because it seems possible to trace the shifts in bargaining power between the distributors and manufacturer as the product's expectations of consumer acceptance fluctuated. As producers of a fairly undistinguished "felt base," territories were nominally exclusive and effectively closed; 30 at the introduction of the promising, new Sandran, multiple distributorships were established; it was in the face of product failure and the subsequent adversity that the company fell back on closed territories.

Though such observations lend credence to the plaint that a company that closes its territories is not likely to be at the onset of a trail towards monopoly, 81 they leave open the question of why Sandura still wants closed territories today. As the Commission noted in its opinion, there are indications that Sandura's financial position has improved considerably in the past years.82 And whatever the company's problems may have been in securing dealers at one time, it seems to have succeeded in developing, albeit with the promise of closed territories, an elaborate distribution system. Of course, Sandura might fear that to remove the security provisions would still be adverse enough to its distributors and potential distributors to cause a net loss of outlets for which the possibly countervailing advantages of open territories

79194 F. Supp. at 585.

80 See note 37 supra and accompanying text.

81 "Respondent is more likely to be absorbed by its larger competitors or driven out of the industry than it is to monopolize the industry. Respondent's problem is to stay in the industry." Brief of Respondent, p. 13, Sandura Co., No. 7042, FTC. June 13, 1962.

82 See notes 40 \& 58 supra. 
would not compensate. In fact, in this respect Sandura's position could well be more precarious than that of White, for distributors in the floor covering industry tend to handle a host of goods of various manufacturers 83 and thus the cost to them of dropping Sandura's products would not include leaving the floor covering business altogether (abandoning all the good will and contacts one has developed over the years), but perhaps only in the reapportionment of warehouse space and salesmanship efforts from one product to another. ${ }^{84} \mathrm{But}$ even if the opening of territories did not discourage a number of distributors from handling the Sandura line, there would remain other reasons why Sandura might wish to retain closed territories.

To understand the continuing services a manufacturer such as Sandura could be anticipating from its distributors in exchange for closing territories, one must begin analysis at the retail level. The dealer in hard-surface floor covering goods, who may be a large department store, a hardware store or a special floor covering retailer, typically handles a broad selection of the various products of Congoleum-Nairn, Armstrong and Pabco (the "Big Three"), 85 as well as of Bird \& Son, Bonafide Mills, Azrock, B. F. Goodrich, Robbins, Kentile, Goodyear, Johns-Manville, New London Mills, Sandura, and others. 86 To the extent that a shopper is not "pre-sold" on one line rather than on another, the dealer has a measure of influence over the purchase and, hence, over the sales of each of the lines he handles. This is something like the power of a retail druggist to foist off on an undecided customer one brand of cough syrup over another-favoring the brand which gives him the highest markup. The resale price maintenance which Sandura attempted on the retail level 87 can probably be explained by the existence of this dealer power plus the fact that unlike products such as cigarettes, which are typically not price maintained, floor covering is expensive enough so that a person who is going to pay the money to lay flooring in his home is likely to canvass several stores before he makes a decision. Insofar as a dealer has power to influence the purchaser towards one product rather than another, he is not apt to emphasize one brand as his "best buy" if the dealer knows the customer will cross the street in a few minutes and find that "best buy" selling ten cents per yard cheaper, or remember that he saw it advertised for less across town. By limiting price competition among dealers. Sandura may have reduced its sales potential in some outlets; but such sales may have been more than made up for by widespread and enthusiastic promotion.

83 See note 88 infra.

84 Even for a White distributor, reapportionment between brands is possible; the Connecticut White Motor Co. (a distributor) has recently taken on the lines of Divco trucks and Willys Jeep, while retaining its White account.

85 See note 35 supra.

${ }^{86}$ Transcript 309, 598, 600, 603, 618-20. Brief of Respondent, p. 14, Sandura Co., No. 7042, FTC, June 13, 1962.

${ }^{87}$ Sandura Co., No. 7042, FTC, Initial Decision at 24 ff., Sept. 15, 1961. 
Floor covering distributors, too, handle a variety of rival products. 88 Thus, as with the retailer, the distributor is prepared to offer whatever influence over sales that he might have in behalf of the manufacturer who pays him best for it. In this respect, the security closed territories provide may induce a distributor to swing sales away from other products and towards Sandran, other factors being equal. Consider, for example, the position of a distributor who handles Kentile, Pabco, Wilson, and Goodrich floor covering as well as Sandura's. In trying to sell a dealer on one of these brands, the distributor must take into account the fact that making a convincing pitch for one line or another is only half the sale. He may persuade the dealer that Kentile is his best buy, but, even so, he may only be inducing the dealer to hold out for a better offer from a neighboring Kentile distributor. Knowing, however, that Sandura's closed territories preclude a neighboring Sandran distributing rival from taking his sale, the distributor knows that if he "sells" a dealer on Sandran, the account will be his. The distributor is thus encouraged to trade the dealer over towards Sandran rather than towards other goods in his inventory. The concomitant effect, that each distributor may be able to advance the price of Sandran a little above the competitive level, and for this reason dampen output, may be overcome by the impact of expanded sales effort.

Of course, closing territories is not the only means by which Sandura could have encouraged such favored treatment. In theory, at least, a monetary equivalent could be assigned to the closing of territories, the sum of the reduced price that retailers would be willing to pay if they had alternative suppliers to deal with, plus, perhaps, the added expenses of competitive selling. If the parties could agree upon such a figure, the net distributor margin per sale could be preserved by Sandura's cutting its own price to the distributors. But this alone would not provide the incentive to push Sandran that closed territories provided, for it would fail to provide the assurance that the efforts of developing Sandran accounts would not be vitiated by a neighboring distributor's predatory behavior in the future. This does not mean that there is no monetary equivalent with which Sandura could purchase the selling efforts associated with closed territories. But suppose there is a floor covering distributor who is dealing with a retailer located 150 miles from the nearest rival distributor of Sandran and 300 miles from the next nearest distributor of Pabco products. If his markup on comparable Pabco goods is twenty cents a square yard, how great a markup on Sandran would he have to have before he would push Sandran rather than its Pabco counterpart? The Pabco rival has an extra 150 miles of freight absorption if he wants to come in and put up a fight; considering the business in his own neighborhood, would that be worth his while? Will the nearby Sandran distributor be willing to live-andlet-live? Opening territories would introduce a new cost-the risk of mis-

88 See Proposed Findings by Counsel Supporting the Complaint, pp. 90-93, and citations to the transcript therein. 
placed effort-the value of which might prove so difficult to ascertain as to make remuneration impractical or prohibitive for the marginal manufacturer.

As an alternative to closed territories, resale price maintenance could play somewhat the same role in developing distributor enthusiasm. Assurance that neighboring distributors could not undercut price might bring forth an extra measure of selling effort, although competition in non-price factors would remain to ward off the interest of the more conservative distributors. But, however the added competition and reduced distributor security might balance out the manufacturer's interests in theory, even in those states in which resale price maintenance is legal, 89 difficulties of policing the agreement would quite likely make the practice a less satisfactory alternative than closed territories. Since "secret shoppers" would be impractical as a means of determining violations of resale price maintenance among distributors, Sandura would have to rely on copies of distributor-dealer price invoices to determine whether there had been price cutting. 90 But the figure which appears on an invoice is inconclusive of the actual price paid; a distributor could circumvent the agreement and avoid detection as easily as by affixing the agreed-upon price on the dealer's invoice and turning over a secret rebate.91 For this reason, a distributor who suspects a rival of price cutting is hardly to be placated by being shown a copy of the invoice as proof that the resale price maintenance agreement had not been violated. Violations of a closed territorial agreement, however, are more incontestably proven. This is because each roll or package of Sandran products bears what is known as a register number, no two rolls or packages bearing the identical number. $92 \mathrm{~A}$ distributor who suspects a dealer in his territory to be taking on outside goods has only to check the numbers in the dealer's stock and compare them with the numbers on goods he has listed in his own records. If he finds his territory has been invaded, the register number will also enable him to locate and confront his infringing rival. Again, this is not to say that Sandura wanted to prevent intrabrand competition in itself. (When, for example, Sandura's own agents discovered and mailed to the front office a package of goods proving the Indianapolis distributor had sold in the Cincinnati distributor's closed territory, the decision was not to mention this to the Cincinnati distributor.) ${ }^{93}$ But if assurance of conformity to a price stabilizing scheme was what distributors

89 As exempt from Sherman Act prosecution under the Miller-Tydings Act, 26 Stat. 209 (1890), as amended, 15 U.S.C. \& 1 (1958).

90 "Secret shoppers" could drop in anonymously on retailers to find out what price they were charging the public. See Complainant's Exhibit 139. But the chances of a hired agent posing as a retailer and "taking in" a distributor would not be as great.

91 Sandura required its distributors to submit invoices to dealers, according to Proposed Findings by Counsel in Support of the Complaint, p. 37. The possibility that these invoices might be doctored is there suggested by the FTC trial counsel, Mr. Brockman Horne.

92 Transcript 206-09, 585.

93 Proposed Findings by Counsel in Support of the Complaint, pp. 62-63. 
demanded in return for expanded efforts in behalf of Sandura products, closed territories and register numbers lent themselves to better assurance than would have resale price maintenance and invoices, and to that extent were probably preferable.

Another reason why closed territories may have been peculiarly well-suited to Sandura's purposes relates to the degree to which a retailer can influence a purchaser towards one brand rather than another. Sandura's distributors may have known that where a retailer could most profitably sell, say, only six rolls of Sandran (that is, the cost to the dealer of selling the seventh, eighth, ninth and tenth rolls might be a front window display, prime floor area, or a local newspaper advertisement which would yield a greater return if invested in another line of goods), he would, by additional effort, sell ten rolls if he were "choked" by being given the "alternative" of selling ten rolls of Sandran or none at all. Given the choice of taking on ten rolls or losing his franchise, he will push the marginal rolls. This is the economic equivalent of "block-booking" and "full-line forcing" in other industries.94 It ought to be noted that under an open system of distribution, a retailer would do business with the distributor who dropped off the number of rolls the retailer would find it most profitable to sell; as one retailer explained, other lines like Armstrong and Congoleum-Nairn had several distributors calling on the trade and "each salesman from each distributor is trying his utmost to make a sale, in contrast to [Sandura] where you have just one distributor and one salesman, and you have to play his way, instead [of his] playing your way, in order to get merchandise. ... [I]n other lines you have two or three salesmen fighting for the particular order ...."95 The record shows instances in which Sandran retailers either lost or suffered a six-month suspension of franchise for not selling all the goods they had "taken on"-a method of stepping up sales singularly facilitated by closing territories.

In its brief before the full Commission, Sandura emphasized as a reason for closing territories that it provided distributors with incentive to lay out advertising expenditures. It will be recalled that the company had no money available for advertising in 1951, 1952 or 1953, and only 24,000 dollars was spent in 1954.96 By way of contrast, after territories were closed, individual distributors spent up to 50,000 dollars on advertisements. ${ }^{97}$ It is not to be supposed that such contributions cost the company nothing, for the necessity of the distributors conducting their own advertising campaign must have been re1957).

94 See ADAMS, The StRUCTURE OF AMERICAN INDUSTRY 365 \& n.6, 316 \& n.73 (rev. ed.

95 See Proposed Findings by Counsel Supporting the Complaint, pp. 43-44.

96 See note 48 supra.

97 Transcript 1357-59. This distributor's sales were the highest of those testifying, $\$ 1,497,000$. The average expenditures of the eight distributors testifying was $\$ 28,044$. See Brief for Respondent, Sandura Co., No. 7042, FTC, June 13, 1962, p. 27. 
fiected in some manner, as by a lower manufacturer-distributor price, or by submitting to a lower turnover than would be possible on the same distributor investment with territories open, or both. But because the distributors, knowing the market, may have been more readily convinced of Sandran's sales potential than the officers of a commercial lending institution (and Sandura's credit position must have been quite low), 98 the cost to Sandura of eliciting advertisements by closing territories may have been less than the cost of borrowing to place advertisements itself. It is not altogether clear, however, why closing territories to elicit advertising contributions should continue to be a profitable device. The claim seems especially dubious in the light of an alternative use to which closed territories might be put: For the company to maximize its income from planning its own advertising investment in a manner which the Robinson-Patman Act makes legally unavailable to firms that distribute through open territories. This possibility arises from the unlikelihood that all Sandura's markets are equally advertising elastic. ${ }^{99}$ In a market in which, for example, the Big Three were waging an extensive local advertising campaign to pre-sell their products, each Sandura promotional dollar might be better spent in giving dealers incentive to push Sandran once the customer gets in the store, rather than to fight an uphill battle in the press. The optimum advertising outlay will probably vary from area to area in accord with the number and quality of the competition, the expenses of advertising in the particular market and the nature of the local consumer. Rationally, a manufacturer ought to vary his advertising expenditure in each area in accordance with the point in that area at which his marginal revenue from advertising equalled the marginal cost. It seems questionable whether Sandura's present system even aims at approximating any such ideal in allowing its distributors to place the advertising. For one thing, it would only be by coincidence that the amount of advertising that maximizes a distributor's revenue would be the optimum outlay from the manufacturer's point of view; for while the extent of advertising will increase the number of units sold by the manufacturer and by the distributors equally, their respective marginal revenues will increase in divers proportions depending on their respective costs and revenues per unit sold. ${ }^{100}$ If the facts are, for example, that Sandura's share of the final sales price is less than a given distributor's, then the distributor, given free rein, would tend to invest more in advertising than

98 See text accompanying notes 39-51 supra.

99 That is, the additional revenue Sandura can expect from an added unit of advertising outlay will vary from one area to another.

100 In other words, suppose that for a given area an additional $\$ 100$ in annual advertising expenditures would increase Sandran sales by 1000 sq. yds. If Sandura were to "net" $\$ 0.15$ a sq. yd. on each sale, it would realize $(1000 \times .15)-100$ or $\$ 50$ on the $\$ 100$ advertising investment. If the distributor is operating on a $\$ 0.05$ margin, it would face a loss of $\$ 50$ if it were to make the same investment: $(100 \times .05)-100$. 
Sandura should care to pay.101 This would not be of concern to Sandura were it not for the fact that Sandura's wholesale price and the yielding of noncompetitive distributor returns means the company is, in a good sense, bearing part of the cost of advertising.102 And because Sandura charges nondiscriminatory rates to each distributor, 103 in making it worth the while of a distributor in Area 1 to lay out 25,000 dollars in local advertising the company would seem to be making a corresponding unit "price" reduction 104 for the distributor in Area 2, where, on a like volume of trade, 12,500 dollars in local advertising might maximize Sandura's revenues. To tailor the costs of advertising to its own needs, it would seem that the company should either (1) charge higher, non-discriminatory prices to each distributor but make advertising allowances of 25,000 dollars to the first and 12,500 dollars to the second, or (2) charge discriminatory prices for the materials, reducing the charge to the first distributor enough so that, and on the condition that, he will place at least twice the advertising value of the second distributor. To most manufacturers, such a scheme would be effectively barred by the Robinson-Patman Act's prohibition on discriminatory prices or discriminatory advertising allowances to customers who are in competition. ${ }^{105}$ Sandura's distributors would have been in competition, and so such a scheme would have been impossible, until territories were closed. Thereafter, might it not be said that discrimination could no longer impair competition between them? Of course, if the courts were to validate closed territories, and allow that closing territories precludes a violation of the Robinson-Patman Act, not

101 And, conversely, if Sandura's marginal revenue were more, the distributor would not advertise as much as Sandura would want it to. Equivalent alternative costs are assumed.

102 We assume that if Sandura itself advertised, an adjustment more favorable to it would have to be reached with respect either to wholesale price or the closing of territories.

103 Sandura uses a zone system of pricing, having divided the country into eight zones. See Complainant's Exhibit 3E.

104 Included within "price" is the measure of value a manufacturer transfers to a distributor when he awards closed territories.

105 "(d) It shall be unlawful for any person engaged in commerce to pay or contract for the payment of anything of value to or for the benefit of a customer of such person in the course of such commerce as compensation or in consideration for any services or facilities furnished by or through such customer in connection with the processing, handling, sale, or offering for sale of any products . .. unless such payment or consideration is available on proportionately equal terms to all other customers competing in the distribution of such products...."

"(e) It shall be unlawful for any person to discriminate in favor of one purchaser against another purchaser or purchasers of a commodity bought for resale . . . by . . . furnishing, or by contributing to the furnishing of, any services ... connected with the ... offering for sale of such commodity . . . upon terms not accorded to all purchasers on proportionately equal terms." 49 Stat. 1527 (1936), 15 U.S.C. § 13(d), (e) (1958). (Emphasis added.) Section (e) omits reference to the purchasers being in competition, as it does to "course of commerce," but the one would probably be read into it as much as the other. 2 Toulmin, ANTI-Trust LAws 65 (1949). Cf. Elizabeth Arden Sales Corp. v. Gus Blass Co., 150 F.2d 988 (8th Cir. 1945). 
only would it be possible to side-step that Act's prohibition on discriminatory advertising rates, but, as a more sweeping result, a powerful manufacturer could segment his distributor's markets and levy the maximizing price in each, a maneuver which seemed relegated to economics text books when the Clayton Act was amended.106

VII.

If the White Motor Company wanted closed territories in order to avoid the prohibitions of the Robinson-Patman Act, there would be less of a mystery as to why it did not simply sign a consent decree. ${ }^{107}$ As an inducement to get distributors to commit themselves to White Trucks, the institution of closed territories was understandable. But once the distributors have put up their initial capital - having estimated the value of their investment as, in part, a capitalization of the advantages of closed territories-one would suspect them to become hemmed in by economic and psychological barriers to exit. For one thing, unlike the floor covering trade, motor truck distributorships tend to handle the product of one manufacturer exclusively, or, if more than one brand is stocked, the brands are apt to be drawn from non-competing categories. This would complicate, at least, an adjustment of efforts between products of various companies. 108 And compounding possible diseconomies of giving up the White line altogether would be the inability to recover anything for the good will one has built up in the White name, an especially disheartening prospect where a large percentage of profits may be derived from the servicing of White trucks. ${ }^{109}$ When one remembers that the alternative to closed territorial distribution would be exclusive territorial distribution-still

106 By a parity of reasoning, the prohibition on discriminatory pricing could be avoided. It is interesting to compare the possibilities suggested by closed territories with the observations on resale price maintenance made by Professor Bowman. He has noted that where there is an overlap between markets in which the product alone is demanded and markets in which the product plus a service is required, resale price maintenance may assure the higher cost service dealer that sales will not be driven off to the lower cost non-service dealer. "[T]he manufacturer must choose between supporting the service dealers or the non-service dealers. If the reduction in total sales occasioned by forcing non-service dealers to sell at prices reflecting costs, as under resale price maintenance, is less than the reduction in sales occasioned by the elimination of dealer service, then the setting of a minimum resale price clearly benefits the original seller." Bowman, The Prerequisites and Effects of Resale Price Maintenance, 22 U. CHr. L. REv. 825, 842-43 (1955). Where large wholesaling markets are involved, the closing of territories and levying of discriminatory prices would meet the needs of the manufacturer Bowman envisions even more favorably than would resale price maintenance (assuming the effect of eliminating cross-selling not to be countervailing). $C f$. ROBINSON, THE ECONOMICS OF IMPERFECT COMPETIIION Ch. 15 (1961); Stigler, The Theory of Price 214-220 (rev. ed. 1952).

107 There was no evidence that such was the case.

108 But to handle various brands of trucks, especially if they are in non-competing categories, is not impossible. See text accompanying note 121 infra.

109 A small interview sampling of truck distributors indicates that net revenues may run as high as two-thirds from parts and services and one-third from truck sales. 
a far cry from plunging the distributors into "cut-throat competition"-it is hard to imagine that opening territories would lead to a crumbling of White's far-flung distributing empire. 110

If wholesale exit of distributors would not undermine White's position, would the impact of open territories on distributors' sales efforts be advantageous or detrimental to the company? White's counsel insist the latter and advance what might be called a fencing-match theory of competition: that the company "has to insist" on closed territories to make "its distributors and dealers concentrate on trying to take sales away from other competing truck manufacturers in their respective territories rather than on cutting each other's throats in other territories."111 Apparently the analysis is grounded on the notion that if left to their own wiles, the distributors would "spread [their] efforts too thinly over more territory than they can vigorously and intensively work."112 One commentator's supposed paraphrase of White's contention is no more convincing: "If the dealer is limited to a defined territory, so the argument goes, he will compete more aggressively in that territory in order to achieve a profitable level of sales, and thus produce lower rather than higher prices to the consumer."'113 Perhaps it is not wrong, but only ironic, to be asked to sympathize with the plight of the White distributors, bent beneath the bargaining weight of a company that calculatingly suffers each of them to hold a monopoly of the White line in his area. On the other hand, it is a striking departure from traditional economic assumptions to suppose that, like starved lions, the distributors become more "aggressive" because of their mistreatment; that in fact, though monopolists, 114 they become so aggressive that the price of trucks falls lower than it would have been had the company thrust them into competition. ${ }^{115}$

110 The district court found that White trucks are sold to over 200 persons, firms or corporations, called "franchise distributors," who in turn may sell to over eighty franchised dealers. 194 F. Supp. at 564. 1962 MOODY's INDUSTRIAL MANUAL 2841 notes that White's dealer organization extends to seventy foreign countries.

111 Brief for Defendant in Opposition to Plaintiff's Motion for Summary Judgment, p. 34, United States v. White Motor Co., 194 F. Supp. 562 (N.D. Ohio 1961).

112 Id. at 35.

113 Turner, The Definition of Agreement Under the Sherman Act: Conscious Parallelism and Refusals to Deal, 75 HARv. L. REv. 655, 698-99 (1962). Counsel for White did not themselves advance an argument in this form before the district court-at least so far as appears from their brief. Brief for Defendant, United States v. White Motor Co., 194 F. Supp. 562 (N.D. Ohio 1961).

114 Not, of course, that a White distributor, $W 1$, given a closed territory, has no competition to meet in the sale of trucks. But insofar as the division of territories removes from WI's area a number of competitors (all other distributors of White trucks) and also leaves $W I$ sole benefactor of whatever attraction buyers find in a White truck over and above competing brands offered at the same price-to that extent WI's pricing policies can be expected to tend in the direction of a monopolist's. See note 66 supra.

115 Or, by a parity of reasoning, the difficulty the celebrated manufacturer of refrigerators experienced when he tried to approach the eskimos was that he offered his sales- 
There is no reason why White's contention cannot be formulated in a more palatable fashion. It may be assumed that two White distributors seeking a sale in a given area make White's chances of getting that sale greater than were there only one White distributor competing for it alone. Moreover, the very fact that a given White distributor, $A$, wishes to leave his immediate territory for B's may be taken as an indication that A estimates his chances of making a sale in B's territory as greater than his chances on any comparable investment at home (even incorporating the possibility that $B$, rather than $A$, will win the sale). Thus, at least on first inspection, it appears that allowing each distributor free rein in pursuing whatever he deems his most worthwhile sales will benefit both the manufacturer and the distributor. Assuming such market knowledge on the part of distributors (no worse an assumption than that the manufacturer knows enough to risk calculating the "best" geographical boundaries-from his point of view-by which to seal the distributor in), how can unbounded selection of customers be inimical to the manufacturer? The explanation for a manufacturer's desiring closed territories, notwithstanding these observations, might lie in the fact that, even though White distributor A's foray into B's territory increases White's chances of a sale there, to the extent that A makes sales that would have been made by B anyway, their duplicated sales efforts represent a dissipation of available promotional funds with no return to the manufacturer. Thus, in going into B's territory, the incremental possibility of a sale there for White may be more than countervailed by an over-all reduction in sales probabilities effected by the diversion of limited resources from the less promising territory.116 For this reason, any given distributor's most worthwhile investment may not always coincide with the investment of distributor resources most profitable to the manufacturer. But if this is the crux of a manufacturer's arguments for closed territories, it ought to be noted that if $\mathrm{A}$, after a certain degree of investment, does not like the area assigned to him as much as he likes B's territory, closeting him out of B's territory only stops him from placing extra investment there; it is no guarantee that, denied access to a certain

men too large a commission. If he had cut their commissions in half, each would have had to sell twice as many, plus enough more to make up for the lower margin brought about by the lower selling price.

116 Thus, suppose White distributor $W I$, competes in territory 11 against International Harvester, General Motors, Chrysler, and Ford distributors, and that W2 competes in territory $\$ 2$ against International Harvester and Mack distributors. Assuming equiprobability of making a sale on unit investment, WI's chances of sale in 71 are one in five, and W2's chances in \#2 are one in three. Still assuming equiprobability, if $W I$ can send his investment

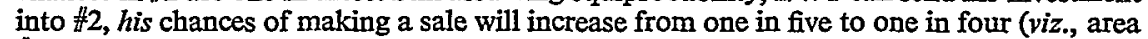
$\# 2$ 's chances will be divided evenly between $I H 2, M 2, W 2$, and $W I$ ), and by the same token W2's chances, which formerly were one in three will fall to one in four. This explains why $W I$ would want to migrate. But notice that from the White Motor Company's point of view, its chances of making a sale on WI's and W2's unit investments were originally eight in fifteen ( $\frac{1}{5}$ plus $\left.\frac{1}{3}\right)$; but after $W 1$ goes into $\# 2$, White's chances fall to one in two on those same investments (zero probability in area $\# 1$ and two in four in area $\# 2$ ). 
risk on the outside, A will transfer his investment to a lesser risk on the inside, rather than place his money and efforts in his next best business alternativefor example, opening a filling station, expanding repair operations, or buying bonds. The cogency of such an argument as White may be trying to advance, so stated, seems to presuppose a distributor for whom potential sales at home are not as attractive as those in his neighbor's territory but are better than his next best business alternative. It is possible that there are manufacturers for whom the distributor transferral of investment to home territories will overcome the effect of sales lost through precluding extraterritorial competition and encouraging some distributor capital to be placed in unrelated enterprises. The possibility seems fairly speculative, and whether such would really be the case with White, perhaps only White, if any one, knows. Some may find it no more reasonable an explanation for White's not having signed a consent decree than, conceivably, a fear that a consent decree would not constitute a valid defense to a breach of contract action brought by the distributors, 117 or a belief that only the motions of a court fight would assuage distributor hard feelings if they had, rather suddenly, to be abandoned on the altar of competition.

\section{VIII.}

To the extent closed territories may enable a manufacturer to augment his market share at the expense of his rivals, rather than to join them in a horizontal plan that would limit output, a closed territorial system may well have effects consistent with the ends of competition. A small company which is otherwise an insignificant competitive factor may be able, through closed territories, to command enough distributor efforts to threaten the market position of established firms and precipitate price competition in an oligopolistic industry. The intrabrand competition that society would thus forego might be more than offset by increased interbrand competition in the product market. Moreover, insofar as having more competitors rather than less may be regarded as in itself a worthwhile antitrust objective, the ability of closed systems to facilitate entry and to forestall exits and mergers militates in favor of the legality of the arrangements. Indeed, by preventing overlap of distributor efforts, closed territories may serve a manufacturer by allocating his distributor's resources in the manner he would dictate if he owned them. Where this is so, forbidding closed territories could conceivably foster forward vertical integration, furthering the disappearance of independent distributors. 118

Though these observations may lend a measure of support for closed territories, they still leave doubts as to the advisability of indulging the distribu-

117 Cf. United States v. Carter Prod., Inc., Trade Reg. ReP. (1962), TRADE CAs. ๆ 70,547 at 77,200 (S.D.N.Y. Oct. 30, 1962).

118 See the dissenting opinion of Douglas, J., in Standard Oil Co. v. United States, 337 U.S. 293, 315 (1949). 
tion line of commerce in apparently non-competitive returns, even if it should prove to be in the interests of greater interbrand competition. In part, these fears should be allayed by several additional observations that stem from the fact that a manufacturer is not willing to tolerate non-competitive returns building up among his distributors, with concomitant higher resale prices and restricted sales volume. When a product is going through the stages of forming good will, investing in its distribution is a greater risk than when the product has reached a stage of broad consumer acceptance, and, depending upon the investment, a high degree of security may be needed to induce distributor entry and promotion. And, too, when the product is weak, the granting of closed territories (as an alternative, for example, to exclusive territories) is not as inimical to the manufacturer as it would be when the product is strong. Initially, territories may be large enough relative to their sales potential that sales to be gained through increased efforts more than offset those lost by the prevention of intrabrand rivalry; as long as this is the case the arrangement should prove tolerable to the manufacturer.

But as a manufacturer's product becomes more established in the market, the supposed advantages of fully exhausting the sales potential of a given area will become less attractive to him when held up against the disadvantages of allowing the distributors to pursue policies of higher price and lower turnover than would be possible if territories were opened. And as the manufacturer's capital increases, his need for his distributors to share certain promotional expenses declines. Eventually, too, consumer acceptance and demand may overshadow the need to buy salesmanship effort. Thus, quite possibly, as the product sales become significant enough that the public needs feel wary of allowing the product to be distributed through closed territories, so will the manufacturer begin to regard them as a bottleneck restricting the flow of his goods into the market.119

So far as it goes, this defense may command some appeal, but it would be unwise to assume that all manufacturers who seek recourse to closed territories do so solely to obtain distributors or to increase the output of their product. Since, by closing territories, a manufacturer makes his product more valuable in the hands of a distributor than it would be with territories open, some of the value of closed territories may be extracted from the distributors in the form of a higher price, as well as some extracted in receipt of increased selling effort. If so, then closed territories may enable a manufacturer to guard non-competitive returns in the sense that if territories were opened, his distributors would not pay him as much per unit. To the extent this may be the case, even in the

119 White's actions in acquiring, and then furthering, Diamond T and Reo sales in competition with its White distributors indicates one method by which the company could temper the effects of its granting a territorial monopoly in the White line. Conceivably, if a given White distributor succeeds in advancing his resale price too far out of line, a downward manipulation of Diamond T and Reo prices would "keep him honest." Another method might be to mitigate the "pay-over" barrier, see note 2 supra, making it more worthwhile for a distributor to cross-haul. 
instance of a manufacturer who would prefer, ideally, to cast off closed territories, there may be a long period in the course of his growth in which he has not enough power to do so and still maintain the same level of price times output. He may have to satisfy himself, instead, with dividing with his distributors the non-competitive returns of their closed markets, increasing his share of the pie as distributor threats to withdraw needed services become more hollow and his own distributing alternatives increase. But even closed territories can give a product only a limited measure of impetus. The product may level off in sales and the fight for manufacturer-distributor supremacy fall into a limbo, leaving the contestants to wage a continuing bilateral struggle over wholesale price, the territories remaining closed, the position of the public unimproved. It may thus be unwise to assume that natural workings of the manufacturer's growth will assure that he himself will iron out the anticompetitive aspects of closed territories. Also, even where a manufacturer attains such a position that opening territories would be profitable, still the working relationships he has developed over the years may make him very reluctant to set aside a closed system without a court order to do so.

Then, too, the supposed possible virtues of closed territories seem, on close inspection, to be balanced off by contrary and equally plausible vices. True, closed territories might in some instances mean survival for the marginal or failing firm. But so long as the practice is lawful it may block entry of other firms, distributors deciding to stick with goods that give them territorial security rather than risk efforts on a freely channeled newcomer. 120 Also objectionable is the fact that even to the extent a manufacturer's closing of territories is aimed at increasing the output of his product as much as possible, the manufacturer, on one level of analysis, appears to be doing so by holding out the prospects of monopoly gains to get the distributors to handle or give special attention to his products in lieu of someone else's. From this point of view, even if the brand's output increases, the product output will remain constant, or, because of the margin of distributing monopoly power, actually decrease. Indeed, rather than to reduce the number of products in the market, the abolition of closed territories is as likely to increase the accessibility of different goods. As an indication, one of White's Connecticut distributors ceased to handle White alone and took on both the lines of Divco, a manufacturer of pick-up trucks, and Willys Jeep when White began to distribute its recently acquired Diamond $\mathrm{T}$ and Reo trucks in direct competition with him.121 When and if the southern Connecticut Sandura distributor finds further effort to sell Sandran unprofitable, he will doubtless switch emphasis to another of the brands he handles and develop sales for that company.

This raises the question: even if closed territories are a means by which a

120 See Comment, 75 HaRv. L. Rev. 795, 834 (1962).

121 See note 84 supra. One of the economic effects of White's distributing nominally rival brands in competition with distributors of its own brand is to limit the latter's ability to retain non-competitive gains without violating White distributor franchises. 
manufacturer seeks to battle (rather than to collude with) his rivals, could the court not insist that he do so by recourse to devices less restrictive on intrabrand marketing? Of course, given a manufacturer who has selected closed territories over alternative means of distribution, one may suppose that closure was his most profitable course of action. This suggests that if closed territories are abolished, the relative power of manufacturers who had recourse to them will decline. As has been noted, this does not necessarily mean that there will be fewer goods or fewer brand names on the market. Nor is it to be supposed that all manufacturers whose territories are opened will have to sit idly by and watch their distributors fail or take on other lines. More likely, a lower manufacturer-distributor price will ensue, which ought to give the public a chance to obtain the product at a price more reflective of costs of production and distribution and less an index of what a given distributorship "can bear."

\section{CONCLUSION}

The Supreme Court will soon be pressed to decide whether closed territorial distribution is to be condemned as per se unlawful. There are, on this subject, virtually no cases which could be regarded as controlling precedent. For lawyers, this is a little like being deserted in the middle of the sea, and, being a breed of unlimited ingenuity, they are prepared to build themselves a raft of analogies to resale price maintenance, ancillary restraints or exclusive territorial distribution. ${ }^{122}$ Instead, it is suggested that the Court ought to examine the economic underpinnings of closed territorial distribution and dispose of the case in full light of what it announces to be the first principles of antitrust policy.

As a guideline in its determination, the Court should keep in mind the impact of price fixing and allocation of territories among competitors, both of which practices have been adjudged per se unlawful. ${ }^{123}$ In each case, the firms involved renounce rivalry among themselves in favor of a mutually advantageous course of action which subjects the public to higher prices and reduces the number of goods placed before it. A manufacturer's closing of territories, on the other hand, is at least consistent with an aim to increase the output of his product at the expense of his rivals. But this in itself need not constitute absolution from the rule of per se illegality, as witnessed by the judicial treatment accorded tying arrangements. ${ }^{124}$ The legality of closed territories ought ultimately to be judged by reference to their probable impact upon the entire product market, if not upon the whole economy.

Presumably a court does not wish to settle such matters on the level at which opposing counsel hold forth on the inferences that can be drawn from

122 See notes 22-26 supra and accompanying text.

123 See United States v. Socony-Vacuum Oil Co., 310 U.S. 150 (1940); United States v. Addyston Pipe \& Steel Co., 175 U.S. 211 (1899).

${ }^{124}$ A manufacturer's conditioning the sale of one product upon the purchaser's taking another of his products has been said to be per se unlawful, Northern Pac. Ry. Co. v. 
labyrinthic graphs and ambiguous charts trending prices, mergers, returns on capital, costs, and shadowy whatnot. 125 There are, however, some good guesses which one might not too unfairly tender. One is that the very raison d'être of a distributor's wanting closed territories, over and above the protection of exclusives, is the expectation of immunity from competition even when prices in his area rise so high as to attract his neighbors to bear the costs of invasionwhen, from the public's point of view, cross-selling would be most welcome. The increased prices which closed territories would thus seem to effect are not even apt to be offset by competitively desirable increases in output. This is true even though one of the most important reasons for a manufacturer's acceding to closed territories is the expectation of receiving services by virtue of which his product's output will increase; for in holding out closed territories as an inducement for distributors to handle his brand, a manufacturer is, in effect, attracting their efforts away, if not from the disposal of a more competitively distributed brand of the same product, from some other sector of the economy. In fact, the very reasons for which the promise of closed territories facilitates the entries of some firms may make them retard entry, tying up the allegiances of available outlets so as to bar still other potential entrants unless they, too, are prepared to respond with closed territories. Moreover, the argument that vertical integration may be fostered by outlawing closed territories could be a mere spectre; manufacturers weak enough to yield closed territories are not those most likely to risk expending capital to buy up distributorships. 126

In fact, it is possible that some manufacturers who have induced distributor entry with the promise of closed territories will actually be benefitted by a court's invalidating the contracts. Enough distributors who would not otherwise have agreed to invest in the manufacturer's product may find the cost of exit so high that they will accept exclusive territories, compete, and still expend enough promotional efforts to more than compensate the manufacturer for any distributors who drop his line or significantly reduce their efforts in his behalf. If a product (or an industry) is such that distribution capital cannot be retained without allowing a division of territories, a court might well feel that the same investment could be better employed elsewhere, where current prices are high enough to signal entry on a more competitive basis.

The more immediate anticompetitive effects of closed territories may be somewhat mitigated by the possibility that some manufacturers who sought recourse to closed territories when their product was insignificant will find such distribution financially less attractive as their product becomes estab-

United States, 356 U.S. 1 (1958), though, of course, it is a means of competing against one's rivals in the market of the tied product. The per se rule may not be inflexible here. See Note, Dehydrating Process Co. v. A. O. Smith Corp.-A Lesson in Identification, 57 Nw. U. L. REv. 107 (1962).

125 See text accompanying note 133 infra.

126 See Comment, 75 HARv. L. Rev. 795, 834 (1962). 
lished. The same development may serve to increase a manufacturer's bargaining power vis-à-vis his distributors, and, if so, he may be able to wrest the closed territories away before they reach seriously anticompetitive dimensions.

But the suggestion that a manufacturer may withdraw closed territories before they reach seriously anticompetitive dimensions is not only limited praise; it is an unsure prospect. A manufacturer, by promising his distributors closed territories, may be able to charge them more for his product than he otherwise could. This raises the disquieting possibility that a manufacturer who never attains power enough to open his territories may simply manifest his increased strength by exacting from his distributors a higher percentage of their joint non-competitive returns. The public might well prefer that the manufacturer open territories and attract whatever distributor services he can by reducing his price to the distributors-the better to reflect the manufacturer's costs of production. This would allow retailers and consumers, in their turn, to whittle the distributors' new enhanced margins down to the competitive level by playing off one distributor against another.

Nonetheless, as an alternative to the Court's entrenching itself in a per se rule, there may be two sorts of situations in which a producer should be allowed to sustain a defense. The first relates to the promotion of a new product; perhaps closed territorial contracts limited to a reasonable period of time, and not open to renegotiation, should be permissible, especially where the expenses and risks of distribution dampen the possibility of new entrants.127 Here objections to the use of "reasonable" as a standard seem outweighed by the injustice of outright prohibition for want of a more precise criterion. The second exception relates to a failing firm. The facts of Sandura strongly suggest that whatever the wisdom of the Commission's decision striking down the territories in 1962,128 had Sandura not been able to close territories in 1955 after its devastating product failures, the company might well have gone out of existence. Whatever arguments can be mustered against the closing of territories, the permanence and inflexibility of a merger make it more objectionable still.129 Thus, if the Court is willing to allow a "failing firm" to enter into an otherwise indefensible merger, 130 perbaps the door ought to be left open for a failing firm in a concentrated industry to close its distribution territories if it feels that is the best way in which it can sustain

127 Thus, lawfulness would not be accorded a contract that allowed territories to remain closed until the distributors had recovered a certain return on their investment; such would be one possible approach, but a time-limiting clause might be better assurance that an inefficient firm was not being subsidized.

128 See note 58 supra.

${ }^{129}$ See Kessler \& Stern, Competition, Contract, and Vertical Integration, 69 YALE L.J. 1, 5-6 (1959).

130 See International Shoe Co. v. FTC, 280 U.S. 291, 301-3 (1930); but see Sandura Co., No. 7042, FTC, June 13, 1962, at 14-15. 
itself as a viable competitor. 131 But even in this case the closure should be limited in time; if the company cannot put itself back together after a period the Court deems reasonable, the workings of competition ought not to be interfered with further.

The Supreme Court has said:

There are certain agreements or practices which because of their pernicious effect on competition and lack of any redeeming virtue are conclusively presumed to be unreasonable and therefore illegal without elaborate inquiry as to the precise harm they have caused or the business excuse for their use. This ... . avoids the necessity for an incredibly complicated and prolonged economic investigation into the entire history of the industry involved, as well as related industries, in an effort to determine at large whether a particular restraint has been unreasonable-an inquiry so often fruitless when undertaken.132

Assuredly, closed territorial distribution is not to be catalogued with the most objectional of business abuses. But aside from the possible exceptions noted above, the impact of any closed territorial distributorship appears so likely to be anticompetitive that it is difficult to conceive any but the most problematical and burdensome proffer of some saving grace. In such circumstances, the invocation of a rule of per se illegality seems warranted.133

131 Professor Day, who opposes a rule of per se illegality, feels that in all cases, since the restraints "are in effect elements of vertical integration by contract... it would seem that the proper tests should be similar to those applied under the Rule of Reason in vertical integration through mergers ... i.e., "the percentage of business controlled, the strength of the remaining competition [at the buyer and seller levels and] whether the action springs from business requirements or purpose to monopolize." "Exclusive Territorial Arrangements Under the Antitrust Laws-A Reappraisal, 40 N.C.L. REv. 223, 249-50 (1962).

132 Northern Pac. Ry. Co. v. United States, 356 U.S. 1 (1958). Cf. Note on the White case in BNA, A.T.T.R., No. 12, Nov. 10, 1961 at A2.

- 133 Jordan, Exclusive and Restricted Sales Area, Under the Antitrust Laws, 9 U.C.L.A. L. REv. 111, 154 (1962), maintains "where the purpose of the restraint is to foster some legitimate business interest the restraint should be prohibited only if some restraint of competition is clearly discernible." Professor Turner feels "inclined to support the view that territorial limitations-in light of their obvious susceptibility to anticompetitive misuseare more restrictive than necessary to achieve the legitimate goal...." The Definition of Agreement Under the Sherman Act: Conscious Parallelism and Refusals to Deal, 75 HARV. L. REv. 655, 699 (1962). Stanley Robinson would subject the restrictions to the rule of reason because "the practice has a legitimate business purpose ... ." Providing for Orderly Marketing of Goods, 15 A.B.A. ANTITRUST Section 282, 297 (1959). Comment, 75 HARV. L. REv. 795, 828 (1962) opposes closed territories because "the exclusive franchise without more affords a large measure of protection to the legitimate interests involved ...." The author of a case note is dubious of the lower court holding in White because it "precluded the possibility of finding in any later case that the legitimate objectives of territorial security agreements may outweigh the concomitant restrictions on competition." 60 MrCr. L. REv. 1006, 1007 (1962) (Emphasis added in each instance). Aside from the objection that reference to the "Iegitimate" invites the courts to set out upon a circular path, the hopelessness of trying to determine the legality of closed territorial distribution upon such a standard is pointed up by the opposing conclusions these authors derive from what appear to be the same premises. 7 